\title{
EVALUATION OF ANALGESIC ACTIVITY OF MURRAYA KOENIGII AND CORIANDRUM SATIVUM LEAVES EXTRACT IN ANIMAL MODEL
}

\author{
KARTIK SALWE ${ }^{1}{ }^{1}$, MIRUNALINI R ${ }^{1 *}$, JERVIN MANO ${ }^{2}$, MANIMEKALAI K ${ }^{1}$ \\ ${ }^{1}$ Department of Pharmacology, Mahatma Gandhi Medical College and Research Institute, Sri Balaji Vidyapeeth, Pillaiyarkuppam, \\ Puducherry, India. ${ }^{2}$ Scientific Project Manager, Abbott Healthcare Pvt. Ltd, Mumbai, Maharashtra, India.
}

Received: 21 September 2017, Revised and Accepted: 24 October 2017

\section{ABSTRACT}

Objective: The objective of the study was to investigate the analgesic activity of hydroalcoholic extract of Murraya koenigii and Coriandrum sativum leaves and compared it with standard drug in an animal model.

Methods: Hydroalcoholic extracts of $M$. koenigii and $C$. sativum leaves were obtained using Soxhlet apparatus. The central analgesic property was screened by hot plate method in mice and tail flick method in rats. The pain reaction time (PRT) was measured at 30, 60, and 120 min. The peripheral analgesic activity was evaluated by acetic acid induced writhing in mice.

Results: In hot plate method M. koenigii leaves extract at both doses and tramadol showed significant increase in PRT at 30, 60, and 120 min compared with control group. C. sativum leaves extract showed significant increase in PRT only at 60 and 120 min compared to control group. In tail flick method M. koenigii leaves extract at both doses, higher dose of $C$. sativum leaves extract and tramadol showed significant increase in PRT at 30, 60, and 120 min compared with control group. Higher dose of $M$. koenigii leaves extract ( $200 \mathrm{mg} / \mathrm{kg}$ ) was comparable with standard drug tramadol in both the methods. M. koenigii leaves extract at both dose showed significant reduction in the number of writhing but $C$. sativum leaves extract failed to show any significant reduction in the number of writhing compared with control. Higher dose of M. koenigii leaves extract was comparable with standard drug tramadol.

Conclusion: M. koenigii leaves extract showed both peripheral and central analgesic effect while $C$. sativum leaves extract showed only peripheral analgesic effect.

Keywords: Analgesic, Acetic acid, Tail flick, Hot plate, Murraya koenigii, Coriandrum sativum.

(C) 2018 The Authors. Published by Innovare Academic Sciences Pvt Ltd. This is an open access article under the CC BY license (http://creativecommons. org/licenses/by/4. 0/) DOI: http://dx.doi.org/10.22159/ajpcr.2018.v11i1.22718

\section{INTRODUCTION}

Pain is protective warning signal, primarily protective in nature, but causes discomfort and suffering. It is the most important symptom that brings the patient to physician. Inflammation and pain are common non-specific manifestations of many diseases. Although nonsteroidal anti-inflammatory drugs and opiates have been used classically in these conditions, some adverse reactions occur with these drugs such as gastrointestinal disturbances, renal damage, respiratory depression, and possible dependence $[1,2]$.

It is, therefore, essential to find out novel effective analgesic agents with minimum side effects. Medicinal plants have been repeatedly considered as one of the main sources of medicines for the treatment of several health problems in humans. In India, $65 \%$ of the population in rural areas uses medicinal plants to help meet their primary healthcare needs [3].

Despite such intensive research on various herbal medicines, many species of plants are still left unexplored. Murraya koenigii and Coriandrum sativum one such highly valued plant used for seasoning in Indian cooking.

M. koenigii, commonly known as "Curry patta" has wide array of properties that include antidiabetic, hypocholesterolemia, antidiarrheal, antimicrobial, anti-inflammatory, and antiulcer activities $[4,5]$. C. sativum is commonly known as "Dhania" possesses antidiabetic, hypolipidemic, and antibacterial activity [6-8].
From the perusal of literature it appears that, of all the biological effects studied on M. koenigii and C. sativum, the analgesic activities have been less investigated. Therefore, the present study was planned to evaluate the analgesic activity of $M$. koenigii and $C$. sativum leaves extract in experimental models.

\section{METHODS}

Collection and identification of plant materials

M. koenigii (curry leaf) and C. sativum (Dhania) were collected from the local market and authenticated by botanist. The leaves were then carefully cleaned, shade-dried, powdered, and stored in an airtight container for use.

\section{Preparation of extract}

The powder of both plants was extracted according to the procedure of Mahanta and Mukherjee using Soxhlet apparatus [9]. A total of 40-45 g of dried powder of each plant was packed in thimble and extracted using $70 \%$ ethanol and $30 \%$ distilled water (i.e., hydroalcoholic extract) at $5-55^{\circ} \mathrm{C}$ from morning $8 \mathrm{am}$ to $4 \mathrm{pm}$ for 6 days (total $48 \mathrm{~h}$ ). The extracts were concentrated in a ventilated oven at $45^{\circ} \mathrm{C}$ for $24 \mathrm{~h}$. It was dissolved in $0.5 \%$ carboxymethyl cellulose (CMC) before administering it to the experimental animals. The extracts were freshly prepared each time before using it in experiment.

\section{Drugs and chemicals}

Tablets of diclofenac sodium and tramadol of Novartis, Mumbai, were procured from local medical store. All other solvents and chemicals 
of analytical grade used were obtained from SD fine - chemical, Mumbai.

\section{Ethical clearance}

Ethical clearance was taken from Institutional Animal Ethics Committee of the institute before commencement of the study.

\section{Animals}

Experimental animals used in this study were Wistar albino rats weighing $140 \pm 10 \mathrm{~g}$ and Swiss albino mice weighing $25 \pm 5 \mathrm{~g}$ of either sex. All animals were procured from King's Institute, Guindy, Chennai, and housed in central animal house of institute. The animals were housed in polypropylene cages, with dry paddy husk bedding and covered with stainless steel mesh lid. The environment of the room was maintained on a 12 -h light/dark cycle at a constant room temperature of $26 \pm 2{ }^{\circ} \mathrm{C}$ and relative humidity of $45-55 \%$. The rats and mice had free access to standard rat and mice chow diet, respectively, and water ad libitum. The rats and mice were acclimatized to the surroundings for 1 week before the experiment. The animals were cared as per the guidelines of Committee for the Purpose of Control and Supervision of Experiments on Animals, New Delhi, India.

\section{Animal experimental design \\ Central analgesic activity \\ Hot plate method}

Swiss albino mice weighing $25 \pm 5 \mathrm{~g}$ of either sex were used and divided into six groups of six animals in each group. Group 1 received 1\% CMC orally as vehicle and was considered as control group. Group 2 and Group 3 received M. koenigii leaves extract at the dose of $100 \mathrm{mg} / \mathrm{kg}$ and $200 \mathrm{mg} / \mathrm{kg}$ body weight orally, respectively. Group 4 and group 5 received C. sativum leaves extract at the dose of $100 \mathrm{mg} / \mathrm{kg}$ and $200 \mathrm{mg} / \mathrm{kg}$ body weight orally, respectively. Group 6 received tramadol at a dose of $13 \mathrm{mg} / \mathrm{kg}$ orally and served as the standard control [10]. All the groups received same volume of preparations. The temperature of the hot plate was maintained at $55 \pm 1^{\circ} \mathrm{C}$, mice were placed on the hot plate and the pain reaction time (PRT), or latency period determined with a stopwatch was recorded, which represented the time taken for the mice to react to the pain stimulus (paw licking or jumping) [11]. Cutoff time in the absence of response was $15 \mathrm{~s}$ to prevent the animals being burnt. Observations were made after administration of respective drugs at an interval of 30,60, and $120 \mathrm{~min}$.

\section{Tail flick method}

Wistar albino rats of either sex were used and divided into six groups of six animals in each group. Group 1 received 1\% CMC orally as vehicle and was considered as control group. Group 2 and Group 3 received M. koenigii leaves extract at the dose of $100 \mathrm{mg} / \mathrm{kg}$ and $200 \mathrm{mg} / \mathrm{kg}$ body weight orally, respectively. Group 4 and group 5 received C. sativum leaves extract at the dose of $100 \mathrm{mg} / \mathrm{kg}$ and $200 \mathrm{mg} / \mathrm{kg}$ body weight orally, respectively. Group 6 received tramadol $9 \mathrm{mg} / \mathrm{kg}$ and served as the standard control [10]. Rats were placed into restrainer leaving tail exposed outside restrainer. A light beam was focused (exerting radiant heat) to the proximal third of the tail. PRT, i.e., tail flick was measured and recorded [12]. A cutoff time of 20s was imposed as a protection against tissue damage. Before doing actual experiment albino Wistar rats were screened for sensitivity test. Any animal that failed to withdraw its tail within $5 \mathrm{~s}$ was rejected from the study. Observations were made after administration of respective drugs at an interval of 30,60, and $120 \mathrm{~min}$.

\section{Peripheral analgesic activity}

Acetic acid induced writhing test

The peripheral antinociceptive activity of M. koenigii and C. sativum leaves extracts were assessed using acetic acid induced writhing test (abdominal constriction test) in mice [13]. Swiss albino mice weighing $25 \pm 5$ g of either sex were used and divided into six groups of six animals in each group. Acetic acid solution $(0.6 \%)$ in a dose of $10 \mathrm{ml} / \mathrm{kg}$ was injected intraperitoneal (i.p) to all the animals, $30 \mathrm{~min}$ after the administration of the test drug. Group 1 received 1\% CMC as vehicle orally and was considered as control. Group 2 and Group 3 received M. koenigii leaves extract at the dose of $100 \mathrm{mg} / \mathrm{kg}$ and $200 \mathrm{mg} / \mathrm{kg}$ body weight orally, respectively. Group 4 and Group 5 received C. sativum leaves extract at the dose of $100 \mathrm{mg} / \mathrm{kg}$ and $200 \mathrm{mg} / \mathrm{kg}$ body weight orally, respectively. Group 6 received diclofenac sodium $10 \mathrm{mg} / \mathrm{kg}$ body weight orally and served as the standard control [14]. The numbers of contraction of the abdominal muscles together with stretching of hind limbs (writhes) were noted for $30 \mathrm{~min}$, and percent inhibition of writhing was also calculated.

\section{Statistical analysis}

The results were presented as mean \pm standard deviation. Statistical analysis was performed using one-way analysis of variance followed by post hoc test Bonferroni. $\mathrm{p}<0.05$ was considered as statistically significant.

\section{RESULTS}

Effect of M. koenigii and $C$. sativum leaves extract on PRT by hot plate method

The result showed that there was no significant difference in the PRT during the pre-drug testing time ( 0 minutes $)$ in all groups. The group which received M. koenigii leaves extract at $100 \mathrm{mg} / \mathrm{kg}$ bw and $200 \mathrm{mg} / \mathrm{kg}$ bw showed a significant increase in PRT compared to control group at 30,60 , and $120 \mathrm{~min}$. The group which received C. sativum leaves extract at $100 \mathrm{mg} / \mathrm{kg}$ bw and $200 \mathrm{mg} / \mathrm{kg}$ bw showed a significant increase in PRT at 60 and 120 min but failed to show increase in PRT at 30 min compared to control group. The group which received a higher dose $(200 \mathrm{mg} / \mathrm{kg} \mathrm{bw})$ of both plant extracts was found better than the lower dose $(100 \mathrm{mg} / \mathrm{kg} \mathrm{bw})$. Standard drug tramadol was found better than both doses of $C$. sativum leaves extract, and lower dose of M. koenigii leaves extract at 30,60, and 120 min but there was no significant difference between a higher dose of $M$. koenigii leaves extract and tramadol at 60 and 120 min (Table 1).

\section{Effect of M. koenigii and C. Sativum leaves extract on PRT by tail flick method}

The result showed that there was no significant difference in the PRT during the pre-drug testing time ( 0 minutes) in all groups. The group which received $M$. koenigii leaves extract at $100 \mathrm{mg} / \mathrm{kg}$ bw and $200 \mathrm{mg} / \mathrm{kg}$ bw showed a significant increase in PRT compared to control group at 30,60 , and $120 \mathrm{~min}$. The group which received $C$. sativum leaves extract at $100 \mathrm{mg} / \mathrm{kg}$ bw showed a significant increase in PRT at 60 and 120 min but failed to show significant increase in PRT at $30 \mathrm{~min}$ while higher dose $200 \mathrm{mg} / \mathrm{kg}$ bw showed significant increase in PRT at 30,60, and 120 min compared to control group. The group which received higher dose $(200 \mathrm{mg} / \mathrm{kg} \mathrm{bw})$ of both plant extracts was found better than the lower dose $(100 \mathrm{mg} / \mathrm{kg} \mathrm{bw})$. Standard drug tramadol was found better than both doses of $C$. sativum leaves extract, and lower dose of M.koenigii leaves extract at 30,60, and $120 \mathrm{~min}$ but there was no significant difference between a higher dose of $M$. koenigii leaves extract and tramadol at 60 and 120 min (Table 2).

Effect of M. koenigii and C. Sativum leaves extract on acetic acidinduced writhing

The groups which received M. koenigii leaves at a dose 100 and $200 \mathrm{mg} / \mathrm{kg}$ bw exhibited a significant reduction in writhing with approximately $30.98 \%$ and $60.56 \%$ of inhibition, respectively, when compared with control group. The groups received C. sativum leaves at a dose 100 and $200 \mathrm{mg} / \mathrm{kg}$ failed to exhibit a significant reduction in writhing with approximately $11.01 \%$ and $16.90 \%$ of inhibition, respectively, when compared with control group. Standard drug diclofenac showed a significant reduction in writhing with approximately $67.60 \%$ when compared with control group. There was no significant difference between higher dose of $M$. koenigii leaves extract and tramadol in reduction in writhing (Table 3).

\section{DISCUSSION}

This study was conducted to investigate analgesic activities of leaves extract of M. koenigii and C. sativum, highly valued plants used for 
Table 1: Effect of oral administration of leaves extract of $M$. koenigii and $C$. sativum on pain reaction time by hot plate method in mice $(n=6)$

\begin{tabular}{|c|c|c|c|c|}
\hline \multirow[t]{2}{*}{ Groups $(n=6)$} & \multicolumn{4}{|c|}{ Reaction time in seconds at various time intervals } \\
\hline & $0 \mathrm{~min}$ & $30 \mathrm{~min}$ & $60 \mathrm{~min}$ & $120 \mathrm{~min}$ \\
\hline Group 1 - Control vehicle & $1.5 \pm 0.5$ & $1.7 \pm 0.5$ & $2.3 \pm 0.5$ & $2.3 \pm 0.5$ \\
\hline Group 2 - MK 100 & $1.5 \pm 0.5$ & $2.3 \pm 0.5^{*}$ & $4 \pm 0.6^{*}$ & $6.5 \pm 0.5^{*}$ \\
\hline Group 3 - MK 200 & $1.7 \pm 0.5$ & $2.7 \pm 0.5^{*}$ & $6.7 \pm 0.5^{*}, \#$ & $8.5 \pm 0.8^{*}, \#$ \\
\hline Group 4 - CS 100 & $1.3 \pm 0.5$ & $1.7 \pm 0.5$ & $4.5 \pm 0.5^{*}$ & $5.5 \pm 0.5^{*}$ \\
\hline Group 5 - CS 200 & $1.2 \pm 0.4$ & $2 \pm 0.6$ & $5.3 \pm 0.5^{*}$ & $6.2 \pm 0.8^{*}$ \\
\hline Group 6 - Tramadol (13 mg/kg) & $1.7 \pm 0.5$ & $5.2 \pm 0.4^{*}$ & $7.2 \pm 0.4^{*}$ & $9.2 \pm 0.4^{*}$ \\
\hline
\end{tabular}

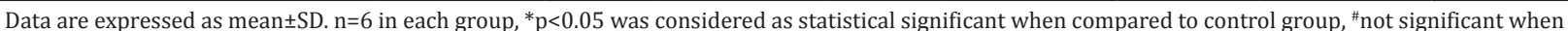
compared to standard tramadol treated group. MK: Murraya konigii leaves extract, CS: Coriandrum sativum leaves extract, $100: 100 \mathrm{mg} / \mathrm{kg}$ bw, 200: $200 \mathrm{mg} / \mathrm{kg}$ bw, SD: Standard deviation

Table 2: Effect of oral administration of leaves extract of $M$. koenigii and $C$. sativum in pain reaction time by tail flick method in rats (n=6)

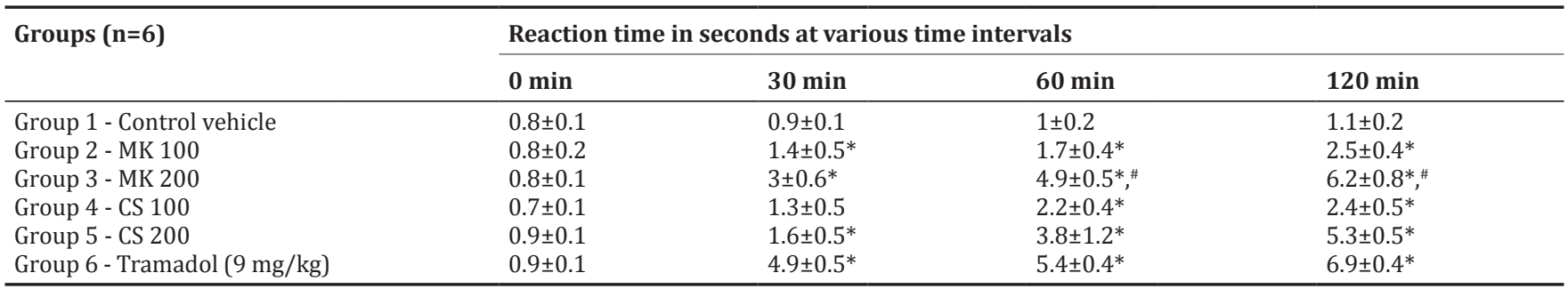

Data are expressed as mean \pm SD. $n=6$ in each group, ${ }^{*} \mathrm{p}<0.05$ was considered as statistical significant when compared to control group, ${ }^{*}$ not significant when compared to standard tramadol treated group. MK: Murraya konigii leaves extract, CS: Coriandrum sativum leaves extract, $100: 100$ mg/kg bw, 200: 200 mg/kg bw, SD: Standard deviation

Table 3: Effect of oral administration of hydroalcoholic leaves extract of M. koenigii and $C$. sativum in acetic acid-induced writhing test in mice

\begin{tabular}{llc}
\hline Groups (n=6) & $\begin{array}{l}\text { Average } \\
\text { number of } \\
\text { writhes }\end{array}$ & $\begin{array}{l}\text { Percent } \\
\text { inhibition }\end{array}$ \\
\hline Group 1 - Control vehicle & $11.8 \pm 1.2$ & 0 \\
Group 2 - MK 100 & $8.2 \pm 0.8^{*}$ & 30.98 \\
Group 3 - MK 200 & $4.7 \pm 1^{*}$ & 60.56 \\
Group 4 - CS 100 & $10.5 \pm 1.2$ & 11.01 \\
Group 5 - CS 200 & $9.8 \pm 0.6$ & 16.90 \\
Group 6 - Diclofenac sodium $(10 \mathrm{mg} / \mathrm{kg})$ & $3.8 \pm 0.8^{*}$ & 67.60 \\
\hline
\end{tabular}

Data are expressed as mean \pm SD. $n=6$ in each group, ${ }^{*} \mathrm{p}<0.05$ was considered as statistical significant when compared to control group, "not significant when compared to standard Tramadol treated group. MK: Murraya konigeii leaves extract, CS: Coriandrum sativum, 100: $100 \mathrm{mg} / \mathrm{kg} \mathrm{bw,} \mathrm{200:} 200 \mathrm{mg} / \mathrm{kg}$ bw, SD: Standard deviation

seasoning in Indian cooking by experimental animal models. We investigated analgesic effect of two plants simultaneously to reduce the number of animals as in separate studies there will be need of extra control group and standard group.

The centrally mediated analgesic activity was evaluated using hot plate and tail flick methods [15]. The time is taken to withdraw tail from the thermal source and paw licking or jumping recorded as PRT in tail flick and hot plate method, respectively. The opioid-like analgesics increase threshold time of such tail flicking and paw licking [16]. These methods have also advantage of differentiating central opioid-like analgesics from peripheral analgesics. The behavior of pain resulting from this method is based on reflex mediated at spinal and supraspinal level. Tail flick is a spinal reflex [17], and hot plate is mostly supraspinally integrated response. Tramadol is considered as a potent opioid analgesic that activates opioid receptors $(\mu, \delta$, and $\kappa)$ through the action on these receptors is weaker than morphine [18].

M. koenigii leaves extract and standard drug tramadol produced a significant increase in PRT compared to control group in hot plate model at 30,60, and $120 \mathrm{~min}$. C. sativum leaves extract failed to show any significant increase in PRN at $30 \mathrm{~min}$ but showed significant increase in PRN at 60 and 120 min when compared to control group. Higher dose of both plants extracts was found better than the lower dose. M. koenigii leaves extract was found better than $C$. sativum leaves extract in increasing the reaction time. Higher dose of $M$. koenigii leaves extract was comparable with standard drug tramadol.

Similar types of results were seen in tail flick method except higher dose of $C$. sativum leaves extract produced significant increase in PRT at $30 \mathrm{~min}$ also. These findings from this study suggest that $M$. koenigii and C. sativum leaves extract has central antinociceptive activity which may be due to their activation of opioid receptors.

The writhing induced by acetic acid is a sensitive procedure to evaluate peripherally acting analgesics. i.p administration of acetic acid in rats irritates serous membranes and provokes a stereotyped behavior in mouse known as writhing.The number of writhes is counted for $30 \mathrm{~min}$ following acetic acid injection. The percentage reduction in the number of abdominal contractions (writhing) indicates the level of analgesia in the acetic acid writhing reflex model [19]. i.p injection of acetic acid causes pain by liberating endogenous substances such as prostaglandins (PGs), serotonin, histamine, bradykinins, and substance $\mathrm{P}$, which stimulate nerve endings [20]. Local peritoneal receptors are postulated to be involved in the abdominal constrictions response [21].

M. koenigii leaves extract at both doses showed significant dose-dependent reduction in the number of writhing when compared to $C$. sativum leaves extract which failed to show significant reduction in the number of writhing when compared with control group. Standard drug diclofenac showed a significant reduction in the number of writhing when compared with the control group but there was no significant difference between higher dose of $M$. koenigii leaves extract and standard drug. This suggest that $M$. koenigii leaves extract has both central and peripheral analgesic activity while $C$. sativum leaves extract exerts only central analgesic activity.

The chemical compounds responsible for the analgesic effect of the extracts were not identified in the present study, and future studies are 
planned. Qualitative phytochemical screening showed the presence of flavonoids, tannins, and alkaloids in M. koenigii leaves extract which may be responsible for analgesic activity as all the three constituents are well known for their ability to inhibit pain perception [22-26]. However, qualitative phytochemical screening of $C$. sativum showed only presence of the flavonoids and polyphenols $[27,28]$. This may be the reason behind the lower analgesic activity of $C$. sativum than M. koenigii.

\section{CONCLUSION}

The present study demonstrates the analgesic activity of two common seasoning plants $M$. koenigii and $C$. sativum. $M$. koenigii leaves extract showed both peripheral and central analgesic effect while $C$. sativum leaves extract showed only peripheral analgesic effect. The analgesic activity may be due to its agonistic action on opioid receptors while the peripheral analgesic effect may be due to inhibition of PG generation. The analgesic activity of $M$. koenigii leaves extract may be due to the presence of alkaloids, flavonoids, and tannins and in $C$. sativum leaves extract due to the presence of flavonoids and polyphenolic compounds. Further elaborative work is necessary for the better understanding of the mechanism of their antinociceptive activity of both plants.

\section{ACKNOWLEDGMENTS}

Authors are thankful for the help of technicians and attenders of Pharmacology Department and Statistician of MGMCRI, Puducherry. We are also thankful to the Sri Balaji Vidyapeeth, Puducherry for funding this study.

\section{REFERENCES}

1. Domaj MI, Glassco W, Aceto MD, Martin BR. Antinociceptive and pharmacological effects of metanicotina, a selective nicotine agonist. J Pharmacol Exp Ther 1999;291:390-98.

2. Farshchi A, Ghiasi G, Khatabi PM, Hossein NA. Ant nociceptive effect of promethazine in mice. Iran J Basic Med Sci 2009;12:140-5.

3. Traditional Medicine. Report by the Secretariat. WHO; 2003. Available from: http://www.apps.who.int/gb/archive/pdf files/WHA56/ea5618. pdf. [Last cited on 2017 Jul 17].

4. Prajapati ND, Purohit, SS, Sharma AK, Kumar TA. Handbook of Medicinal Plants. $1^{\text {st }}$ ed. Jodhpur: Agrobios (India); 2003. p. 352-53.

5. Handral HK, Jha PK, Shruthi SD. Pharmacognostic and phytochemical studies on the leaves of Murraya koenigii (L) Spreng. Pharmacophore 2010;1:231-38.

6. Gray AM, Flatt PR. Insulin-releasing and insulin-like activity of the traditional anti-diabetic plant Coriandrum sativum (coriander). $\mathrm{Br} \mathrm{J}$ Nutr 1999;81:203-9.

7. Nalini N, Sabitha K, Viswanathan P, Menon VP. Influence of spices on the bacterial (enzyme) activity in experimental colon cancer. J Ethnopharmacol 1998;62:15-24.

8. Baratta MT, Dorman HJ, Deans SG, Biondi DM, Ruberto G. Chemical composition, antimicrobial and ant oxidative activity of laurel, sage, rosemary, oregano and coriander essential oils. J Essent Oil Res 1998;10:618-27.

9. Mahanta M, Mukherjee AK. Neutralization of lethality, my toxicity and toxic enzyme of Naja kaouthia venom by Mimosa pudica root extract. J Ethnopharmacol 2001;75:55-60.

10. Sekhar NC, Jayasree T, Ubedulla S, Dixit R, Manohar VS, Shankar J. Evaluation of antinociceptive activity of Aqueous extract of bark of Psidium guajava in albino Rats and albino Mice. J Clin Diag Res 2014;8:HF01-04

11. Eddy NB, Leimbach D. Synthetic analgesics. II. Dithienylbutenyl-and dithienylbutylamines. J Pharmacol Exp Ther 1953;107:385-93.

12. D'Amour FE, Smith DL. A method for determining loss of pain sensation. J Pharmacol Exp Ther 1941;72:74-8.

13. Koster R, Anderson M, De Beer EJ. Acetic acid for analgesic screening. Fed Proc 1959; 18:412-17.

14. Nesa L, Munira S, Mollika S. Evaluation of analgesic, anti-inflammatory and CNS depressant activities of methanolic extract of Lawsonia inermis barks in mice. Avicenna J Phytomed 2014;4(4):287-96.

15. Vogel HG, Vogel WH. Drug Discovery and Evaluation: Pharmacological Assays. Berlin, Germany: Springer; 2007.

16. Tjolsen A, Hole K. Tail-flick test. In: Gebhart G, Schmidt R, editors. Encyclopedia of Pain. Berlin, Germany: Springer; 2013. p. 3832-37.

17. Sinclair JG, Main CD, Lo GF. Spinal vs. Supraspinal actions of morphine on the rat tail-flick reflex. Pain 1988;33:357-62.

18. Fan S, Ali NA, Basri DF. Evaluation of analgesic activity of the methanol extract from the galls of Quercus infectoria (Olivier) in rats. Evid Based Complement Alternat Med 2014;2014:1-6.

19. Hicks R. The evaluation of inflammation induced by material implanted subcutaneously in the rat. J Pharm Pharmacol 1969;21:581-88.

20. Machioro M, Blank MF, Moura RH, Antioniolli AR. Antinociceptive activity of the Aqueous extract of Erythrina velutina leaves. Fitoterapia 2005;76:637-42.

21. Onasanwo SA, Elegbe RA. Anti-nociceptive and anti-inflammatory properties of the leaf extracts of Hedranthera barteri in rats and mice. Afr J Biomed Res 2006;9:109-17.

22. Fernanda LB, Victor AK, Amelia TH. Analgesic property of umbelletin from Psychotria umbellate. Pharm Biol 2004;44:56.

23. Onasanwo SA, Elegbe RA. Antinociceptive and anti-inflammatory effect of the leaf extracts of Hedranthera barteri in rats and mice. Afr J Biomed Res 2000;14:418.

24. Upadhyay K, Upadhyay A. Anti-inflammatory evaluation of ethanolic extract of leaves of Holoptelea integrifolia, planch. Ann Biol Res 2010;1:185-95.

25. Sutar NG, Pal SC. Evalution of analgesic activity of leaf extracts of Pergularia daemia [forsk] in experimental animals. Int J Pharm Pharm Sci 2014;6:137-9.

26. Kaur P, Kashyap P, Katoch N, Gupta S, Singh R. Pharmacological evaluation of hydroalcohol and chloroform extracts of Nyctanthes arbour-tristis L. for antioxidant, anti-inflammatory and analgesic activity. Int J Pharm Pharm Sci 2014;6:460-65.

27. Pathak NI, Kasture SB, Bhatt NM. Phytochemical screening of Coriander sativum linn. Int J Pharm Sci Rev Res 2011;9:159-63.

28. Rylski M, Duriasz-Rowińska H, Rewerski W. The analgesic action of some flavonoids in the hot plate test. Acta Physiol Pol 1979;30:385-8. 